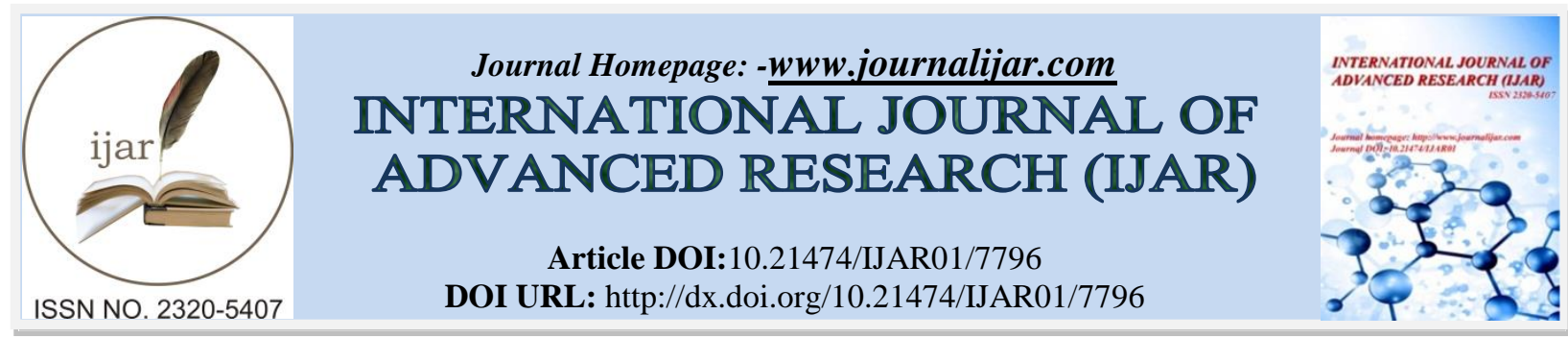

RESEARCH ARTICLE

\title{
STATUS OF VITAMIN A, D, E IN CHILDREN OF JIAMUSI AREA; A CROSS SECTIONAL STUDY.
}

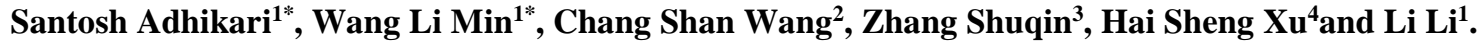 \\ 1. Department of Pediatrics, First affiliated Hospital of Jiamusi University, Jiamusi, China, *First co-authors. \\ 2. College of basic Medicine, Jiamusi University, Jiamusi, China. \\ 3. Changzhou Children Hospital, Changzhou, China. \\ 4. Children's hospital of Nanjing medical university, Nanjing, China.
}

\section{Manuscript Info Abstract}

\section{(1............................}

\section{Manuscript History}

Received: 2 August 2018

Final Accepted: 4 September 2018

Published: October 2018

Keywords:

Vitamin A, Vitamin D, Vitamin E, Deficiency.

\begin{abstract}
Background: Vitamin A, D and E are very essential to normal growth, development and health of children. Deficiencies are being global problem. The objective of this study is to find out the status of serum vitamin A, D, E level in Children below 14 years in Jiamusi city area (latitude $46^{\circ} 48^{\prime} \mathrm{N}$ longitude $130^{\circ} 19^{\prime} \mathrm{E}$ ) of Heilongjiang province in northeast of China.

Methods: Children from birth to 14 years of age who came for normal health check up in First affiliated hospital of Jiamusi University were used to collect blood samples for vitamin A, D, E. Vitamin A and E were measured by High Performance Liquid Chromatography (HPLC) and vitamin $\mathrm{D}$ was measured by liquid chromatography-tandem mass spectrometry from sigma company (USA).

Results: A total of 3365 children were participated in a year time. These samples were categorized according to age, gender and season groups. The mean levels of serum vitamin $\mathrm{A}$, vitamin $\mathrm{D}$ and vitamin $\mathrm{E}$ was $0.06 \mathrm{mg} / \mathrm{L}, 24.24 \mathrm{ng} / \mathrm{ml}$ and $8.56 \mathrm{mg} / \mathrm{L}$ respectively. There was vitamin A deficiency (VAD) $(n=1658,57.6 \%)$, more in $6-14$ year age group $(\mathrm{n}=708,24.6 \%)$ and more in summer season $(\mathrm{n}=552,19.2 \%)$. Similarly vitamin D deficiency (VDD) $(\mathrm{n}=1203,36.9 \%)$ more in 6-14 years age group $(n=756,23.2 \%)$ and in winter season $(n=453,13.9 \%)$ was found. There was significant differences on gender, age group and season for analysis of VAD, $\mathrm{p}<0.05$. Vitamin E deficiency (VED) was significantly more frequent in autumn samples $(\mathrm{OR}=3.34,95 \% \mathrm{CI} 1.20$, 9.28; $\mathrm{p}=0.01$ ). The study showed no significant differences with age group and gender for vitamin $\mathrm{E}$ levels.

Conclusion: The prevalence of VAD, VDD was more in Jiamusi city area children with significant difference of vitamin $\mathrm{E}$ in autumn season. Vitamin deficiencies are more with increasing age group suggesting the timely adjustment of vitamin and need of supplementation to elder children to have a healthy youth in future.
\end{abstract}

Copy Right, IJAR, 2018,. All rights reserved. 


\section{Introduction:-}

Vitamins are essential chemically unrelated to the organic compounds which cannot be synthesized in adequate amount in human body. These are essential for normal growth and development. Vitamin A, D, E are fat soluble vitamin as they are released, absorbed and transported with help of dietary fat.

Vitamin A deficiency (VAD) is a major nutritional problem found in developing, economically poor and illiterate society. The less supply, poor feeding habit, periodic illness and infections are main cause leading to deficiencies of vitamins for the children. This deficiency will fail to meet the physiologic need of our body. This deficiency will impair normal growth and development, normal metabolism, development of immune system and causes many disorders related to vitamin A deficiency like xerophthalmia, anemia, and chances of getting chronic illness [1].

The deficiency of vitamin D (VDD) is more common throughout the pediatric age group which present as signs of rickets including tremor, carpel pedal spasm, failure to thrive, frontal bossing, rachitic rosary, large anterior fontanel, cranoiotabies, Harrison's groove, widened wrists and ankle, bowing of leg. It is also supposed to be associated in autoimmune disease, cancer, endocrinal diseases, high blood pressure and infectious disease [2]. They may also have the chances of having hyper-reflex, developmental delay, delayed dentition and increased chances of having decayed teeth. Also children may present with multiple fractures and bone frangibility. Severe deficiency of vitamin $\mathrm{D}$ can present with seizures and tetany from profound hypocalcaemia. Older children may present with short stature and loss of appetite in VDD [3].

Vitamin $\mathrm{E}$ is the other essential fat soluble vitamin which was not much known vitamin needed to our body in past. This vitamin is having a great role in providing immune function, preventing inflammation, regulation of gene expression and cognitive performance [4]. It is a potent antioxidant. Vitamin E deficiency (VED) is common in population who don't consume the food rich in vitamin E like almonds, germinating seeds, mustard green, spinach, plants oil, avocado, papaya, and broccoli. VED is associated with motor and sensory neuropathy, intestinal fat malabsorption which includes bowel disease, pancreatic disease, chronic cholestasis, celiac disease, cystic fibrosis, short bowel syndrome, intestinal lymphangiectasiswhere as excess of vitamin E may be associated with heart failure, coagulopathy, impaired immunity. But it is said that it's difficult to achieve the vitamin E toxicity [5].

Deficiency of any one of these micronutrients is now becoming a global problem. More over this is mostly common in the population of low socioeconomic status, undeveloped parts of world and place having different climatic state and cultural belief. Heilongjiang province lies in northeast part of china which is having less sunshine, heavy snow fall, low socioeconomic status, backward, remote and less developed than other parts of China. Some of study has shown high prevalence of Vitamin D deficiency. At present there lacks large samples data of vitamin A, D, E in eastern Heilongjiang. This study is aimed to see the prevalence of vitamin A, D and E in Jiamusi and differences with age, gender and season. It plays a guiding role for children's health in Jiamusi area.

\section{Method and Materials:- Study participants}

This study was done in first affiliated hospital of Jiamusi University which lies in north east of China. The children from the nearby cities and villages of Jiamusi city were included. There were 3365 children who participated in the analysis of vitamin A, D,Ewho came for regular heath check up from September 1, 2016 to August $30,2017$. Children with known diseases of rickets, calcium metabolism, renal and liver diseases were excluded. Ethics approval was obtained from the first affiliated hospital of Jiamusi University.

\section{Methods}

The study was done to find the levels of vitamins. We categorized the samples taken according to age where children were divided into four sub classes; 0 1year, 1 <3years, 3 <6years, 6 14years of age, according to the season into four subgroups; autumn (September to end of November), winter (December to end of February), spring (March to end of May) and summer (June to the end of August), according to gender into two subgroups; male and female child. Those children who came for normal health check up were used for our study. The children who did not follow the inclusion criteria were not used in this study. 


\section{Blood samples and biochemical measurements}

Samples were collected from the children visiting first affiliated hospital of Jiamusi University. $2 \mathrm{ml}$ of venous blood was collected for the test and collected in the test tube. The blood was collected in the heparin added test tube and kept away from the light. The test tube was marked with the name of the children and the special code and stored in ice bag. The levels of vitamin were measured by reverse phase high performance liquid chromatography (FT-HPLC) and liquid chromatography-tandem mass spectrometry from sigma company (USA).

\section{Statistical Methods}

Statistical computations were performed using SPSS for windows statistical software package version 23 (SPSS Inc., Chicago, IL, USA). Mean serum levels of vitamin A, D, E were compared between groups by using the $t$ test or analysis of variance where appropriate. Difference between proportions was elevated by Pearson's $X^{2}$ test.

\section{Results:-}

\section{General characteristics}

The study was done in First affiliated hospital of Jiamusi University (JUH) from September 2016 to end of August, 2017. The frequency of distribution of vitamin A, D, E is shown in the figure no. 1 . The total children ( 0 to 14 years of old) were 3365 . The mean serum vitamin A was $0.06 \mathrm{mg} / \mathrm{L}$ (ranging from $0.06-0.60$ ), serum vitamin D was $24.24 \mathrm{ng} / \mathrm{ml}$ (ranging from 1.90-99.90) and serum vitamin $\mathrm{E}$ was $8.56 \mathrm{mg} / \mathrm{L}$ (ranging from $2.00-22.10$ ). There were $\mathrm{n}=1999(59.40 \%)$ and $\mathrm{n}=1366(40.60 \%)$ female children. There were $\mathrm{n}=755(22.44 \%)$ in spring, $\mathrm{n}=1266(37.62 \%)$ in summer, $\mathrm{n}=610(18.13 \%)$ in autumn, $\mathrm{n}=734(21.81 \%)$ in winter. Among these, there were $\mathrm{n}=307(9.10 \%)$ children $0 \sim<1$ year of age, $\mathrm{n}=651(19.3 \% 0)$ children $1 \sim<3$ year of age, $\mathrm{n}=899(26.70 \%)$ children $3 \sim<6$ of age, 1508(44.80\%) children 6 14 years of age in Jiamusi City area. See Table No.1 and Table no.2 for detail general information and the status of vitamin levels in different groups.

\section{Serum vitamin A levels and prevalence of low vitamin A status}

There were 2876 cases (male 1701 and female 1175) for vitamin A sampled in Jiamusi city area. There was prevalence of vitamin A deficiency $(n=1658,57.6 \%)$ with Male $(n=1004,34.9 \%)$ and female $(n=654,22.7 \%)$. The study showed that there was no significant difference in male and female children being $p>0.05$. There was more prevalence of vitamin A deficiency with increasing of age; maximum deficiency was found in 6-14 years child $(\mathrm{n}=708,24.6 \%)$ least deficiency was found in $0-1$ year $(\mathrm{n}=180,6.3 \%)$. There was more prevalence of vitamin A deficiency in summer season $(\mathrm{n}=552,19.2 \%)$. The study showed that difference according to Age group and season being $\mathrm{p}<0.05$. This result was made with the cutoff limit of $0.3 \mathrm{mg} / \mathrm{L}$ for vitamin A deficiency.

\section{Serum vitamin D and prevalence of low vitamin D status}

There were 3258 children (male 1932 and female 1326) for vitamin D sampled. There was prevalence of vitamin D deficiency $(n=1203,36.9 \%)$ with male children $(n=683,21 \%)$ and female children $(n=520,16 \%)$. The study showed significant differences on gender, age group and season with $\mathrm{p}<0.05$. Prevalence of vitamin $\mathrm{D}$ increased with increase of age. Children of 0-1 year age group were having least prevalence of vitamin D deficiency $(n=37,1.1 \%)$ whereas more prevalence of vitamin D deficiency $(n=756,23.2 \%)$ in 6-14 years age group. Most vitamin $D$ deficiency was found in winter $(\mathrm{n}=453,13.9 \%)$ whereas least in summer $(\mathrm{n}=156,4.8 \%)$. This was done with cutoff limit of $20 \mathrm{ng} / \mathrm{ml}$ for vitamin D deficiency. In logistic regression, Vitamin D deficiency was more prevalent in female $(\mathrm{OR}=1.31,95 \% \mathrm{CI} 1.10,1.56 ; \mathrm{p}=0.00), 6-14$ years age group children and winter season $(\mathrm{OR}=16.66,95 \% \mathrm{CI} 12.96$, $21.41 ; \mathrm{p}=0.00)$.

\section{Serum vitamin $E$ levels and prevalence of low vitamin $E$ status}

There was 1785 children (male 1052 and female 733) for vitamin E analysis. It was found that the prevalence of vitamin E deficiency $(n=30,1.7 \%)$ with male children $(n=21,1.2 \%)$ and female children $(n=9,0.5 \%)$. There was more vitamin E deficiency in autumn season $(n=16,0.9 \%)$ whereas less in spring season $(n=3,0.2 \%)$. This study showed that it was significant with season variation being $\mathrm{p}<0.05$. The study showed no significant differences with age group and gender. In logistic regression, Vitamin E deficiency was significantly more frequent in autumn samples $(\mathrm{OR}=3.34,95 \%$ CI 1.20, 9.28; $\mathrm{p}=0.01)$. (See Table no. 3 ) 
Table no.1:-Overall information of samples of vitamin A, D, E in Jiamusi City area

\begin{tabular}{|c|c|c|c|c|c|c|c|c|c|c|c|c|c|c|c|}
\hline \multirow[t]{2}{*}{ Variable } & \multicolumn{5}{|c|}{ Vitamin A } & \multicolumn{5}{|c|}{ Vitamin D } & \multicolumn{5}{|c|}{ Vitamin E } \\
\hline & $\mathrm{n}$ & $\%$ & Mean & $\min$ & $\max$ & $\mathrm{n}$ & $\%$ & mean & $\min$ & Max & $\mathrm{n}$ & $\%$ & Mean & Min & $\max$ \\
\hline Gender & 2876 & & 0.29 & 0.06 & 0.60 & 3258 & & 24.42 & 1.90 & 99.90 & 1785 & & 8.56 & 2.00 & 22.10 \\
\hline Male & 1701 & 59.1 & 0.29 & 0.06 & 0.60 & 1932 & 59.3 & 23.08 & 1.90 & 71.40 & 1052 & 58.9 & 8.37 & 3.20 & 22.10 \\
\hline Female & 1175 & 40.9 & 0.29 & 0.07 & 0.58 & 1326 & 40.7 & 22.54 & 3.40 & 99.90 & 733 & 41.1 & 8.75 & 2.00 & 21.80 \\
\hline Age group & & & & & & & & & & & & & & & \\
\hline $0-<1 \mathrm{y}$ & 243 & 8.4 & 0.26 & 0.09 & 0.51 & 304 & 9.3 & 31.25 & 4.40 & 57.20 & 118 & 6.6 & 10.54 & 3.20 & 22.10 \\
\hline $1-<3 y$ & 506 & 17.6 & 0.28 & 0.09 & 0.57 & 635 & 19.5 & 29.37 & 1.90 & 99.90 & 289 & 16.2 & 9.61 & 4.50 & 19.30 \\
\hline $3-<6 y$ & 783 & 27.2 & 0.28 & 0.06 & 0.60 & 874 & 26.8 & 22.93 & 3.50 & 76.40 & 505 & 28.3 & 8.32 & 2.00 & 18.00 \\
\hline $6-14 y$ & 1344 & 46.7 & 0.30 & 0.06 & 0.58 & 1445 & 44.4 & 19.51 & 3.40 & 71.40 & 873 & 48.9 & 8.02 & 3.90 & 21.80 \\
\hline Season & & & & & & & & & & & & & & & \\
\hline Autumn & 572 & 19.9 & 0.27 & 0.06 & 0.52 & 593 & 18.2 & 23.97 & 1.90 & 99.90 & 461 & 25.8 & 8.30 & 2.00 & 21.80 \\
\hline Winter & 663 & 23.1 & 0.29 & 0.07 & 0.57 & 704 & 21.6 & 17.78 & 3.40 & 57.20 & 418 & 23.4 & 8.57 & 3.50 & 18.60 \\
\hline Spring & 616 & 21.4 & 0.29 & 0.06 & 0.53 & 730 & 22.4 & 19.66 & 4.20 & 68.90 & 402 & 22.5 & 8.54 & 3.20 & 22.10 \\
\hline Summer & 1025 & 35.6 & 0.37 & 0.09 & 0.60 & 1231 & 37.8 & 28.50 & 3.60 & 71.40 & 504 & 28.2 & 8.68 & 4.00 & 20.70 \\
\hline Age(year) & & & 5.61 & 0.08 & 14 & & & 5.18 & 0.08 & 14 & & & 5.80 & 0.08 & 14 \\
\hline
\end{tabular}

Table no. 2:-Status of vitamins in children 0-14 years of children in Jiamusi City area

\begin{tabular}{|c|c|c|c|c|c|c|c|c|c|}
\hline \multirow[t]{2}{*}{ Status } & \multicolumn{3}{|c|}{ vitamin $\mathrm{A}$} & \multicolumn{3}{|c|}{ Vitamin D } & \multicolumn{3}{|c|}{ Vitamin E } \\
\hline & Definition & cases & $\%$ & Definition & cases & $\%$ & Definition & cases & $\%$ \\
\hline Severe Deficiency & $<0.1 \mathrm{mg} / \mathrm{L}$ & 10 & 0.3 & $<5 \mathrm{ng} / \mathrm{ml}$ & 14 & 0.4 & N/A & & \\
\hline Deficiency & $0.1-<0.2 \mathrm{mg} / \mathrm{L}$ & 292 & 10.2 & $5-<15 \mathrm{ng} / \mathrm{ml}$ & 670 & 20.6 & $<5 \mathrm{mg} / \mathrm{L}$ & 30 & 1.7 \\
\hline Insufficiency & $0.2-<0.3 \mathrm{mg} / \mathrm{L}$ & 1356 & 47.1 & $15-<20 \mathrm{ng} / \mathrm{L}$ & 519 & 15.9 & N/A & & \\
\hline Sufficiency & $>=0.3 \mathrm{mg} / \mathrm{L}$ & 1218 & 42.4 & 20-100ng/L & 2055 & 63.1 & $5-20 \mathrm{mg} / \mathrm{L}$ & 1751 & 98.1 \\
\hline Excess & $>1.3 \mathrm{mg} / \mathrm{L}$ & & & $>100 \mathrm{ng} / \mathrm{L}$ & & & $>20 \mathrm{mg} / \mathrm{L}$ & 4 & 0.2 \\
\hline Total & & 2876 & 100.0 & & 3258 & 100.0 & & 1785 & 100.0 \\
\hline
\end{tabular}

Table no. 3:-Prevalence and unadjusted OR with 95\%CI for vitamin A, D, E deficiencies in Jiamusi city area

\begin{tabular}{|c|c|c|c|c|c|c|c|c|c|c|c|c|c|c|c|}
\hline \multirow{2}{*}{ Variable } & \multicolumn{5}{|c|}{ Vitamin A deficiency } & \multicolumn{5}{|c|}{ Vitamin D deficiency } & \multicolumn{5}{|c|}{ Vitamin E deficiency } \\
\hline & $\mathrm{N}$ & $\%$ & OR & $95 \% \mathrm{CI}$ & $\mathrm{p}$ & $\mathrm{n}$ & $\%$ & OR & $95 \% \mathrm{CI}$ & $\mathrm{p}$ & $\mathrm{n}$ & $\%$ & OR & $95 \% \mathrm{CI}$ & $\mathrm{p}$ \\
\hline Gender & 1658 & 57.6 & & & 0.06 & 1203 & 36.9 & & & 0.00 & 30 & 1.7 & & & 0.21 \\
\hline Male & 1004 & 34.9 & $0^{*}$ & & & 683 & 21.0 & $0^{*}$ & & & 21 & 1.2 & $0^{*}$ & & \\
\hline Female & 654 & 22.7 & 0.87 & $0.74,1.01$ & & 520 & 16.0 & 1.31 & $1.10,1.56$ & & 9 & 0.5 & 0.61 & $0.27,1.35$ & \\
\hline Age group & & & & & 0.00 & & & & & 0.00 & & & & & 0.28 \\
\hline $0-<1 \mathrm{y}$ & 180 & 6.3 & 2.51 & $\begin{array}{l}1.84, \\
3.42 \\
\end{array}$ & & 37 & 1.1 & 0.09 & $\begin{array}{l}0.06 \\
0.13\end{array}$ & & 3 & 0.2 & 1.82 & $\begin{array}{l}0.48, \\
6.87\end{array}$ & \\
\hline $1-<3 y$ & 296 & 10.3 & 1.24 & $\begin{array}{l}1.00 \\
1.52\end{array}$ & & 102 & 3.1 & 0.11 & $\begin{array}{l}0.09 \\
0.14\end{array}$ & & 4 & 0.2 & 1.08 & $\begin{array}{l}0.33 \\
3.51\end{array}$ & \\
\hline $3-<6 y$ & 474 & 16.5 & 1.34 & $\begin{array}{l}1.12, \\
1.61\end{array}$ & & 308 & 9.5 & 0.36 & $\begin{array}{l}0.30 \\
0.44\end{array}$ & & 13 & 0.7 & 2.16 & $\begin{array}{c}0.93, \\
5.01\end{array}$ & \\
\hline 6- $14 y$ & 708 & 24.6 & $0^{*}$ & & & 756 & 23.2 & $0^{*}$ & & & 10 & 0.6 & $0^{*}$ & & \\
\hline Season & & & & & 0.00 & & & & & 0.00 & & & & & 0.01 \\
\hline Autumn & 382 & 13.3 & 1.68 & $\begin{array}{l}1.35, \\
2.08\end{array}$ & & 235 & 7.2 & 6.21 & $\begin{array}{c}4.81, \\
8.01\end{array}$ & & 16 & 0.9 & 3.34 & $\begin{array}{l}1.20 \\
9.28\end{array}$ & \\
\hline Winter & 366 & 12.7 & 1.09 & $\begin{array}{l}0.90 \\
1.33\end{array}$ & & 453 & 13.9 & $\begin{array}{c}16.6 \\
6\end{array}$ & $\begin{array}{l}12.96 \\
21.41\end{array}$ & & 6 & 0.3 & 1.44 & $\begin{array}{l}0.43, \\
4.78\end{array}$ & \\
\hline Spring & 358 & 12.4 & 1.15 & $\begin{array}{l}0.94, \\
1.42 \\
\end{array}$ & & 359 & 11.0 & 9.91 & $\begin{array}{c}7.76, \\
12.66\end{array}$ & & 3 & 0.2 & 0.7 & $\begin{array}{l}0.16, \\
2.97\end{array}$ & \\
\hline Summer & 552 & 19.2 & $0^{*}$ & & & 156 & 4.8 & $0^{*}$ & & & 5 & 0.3 & $0^{*}$ & & \\
\hline
\end{tabular}




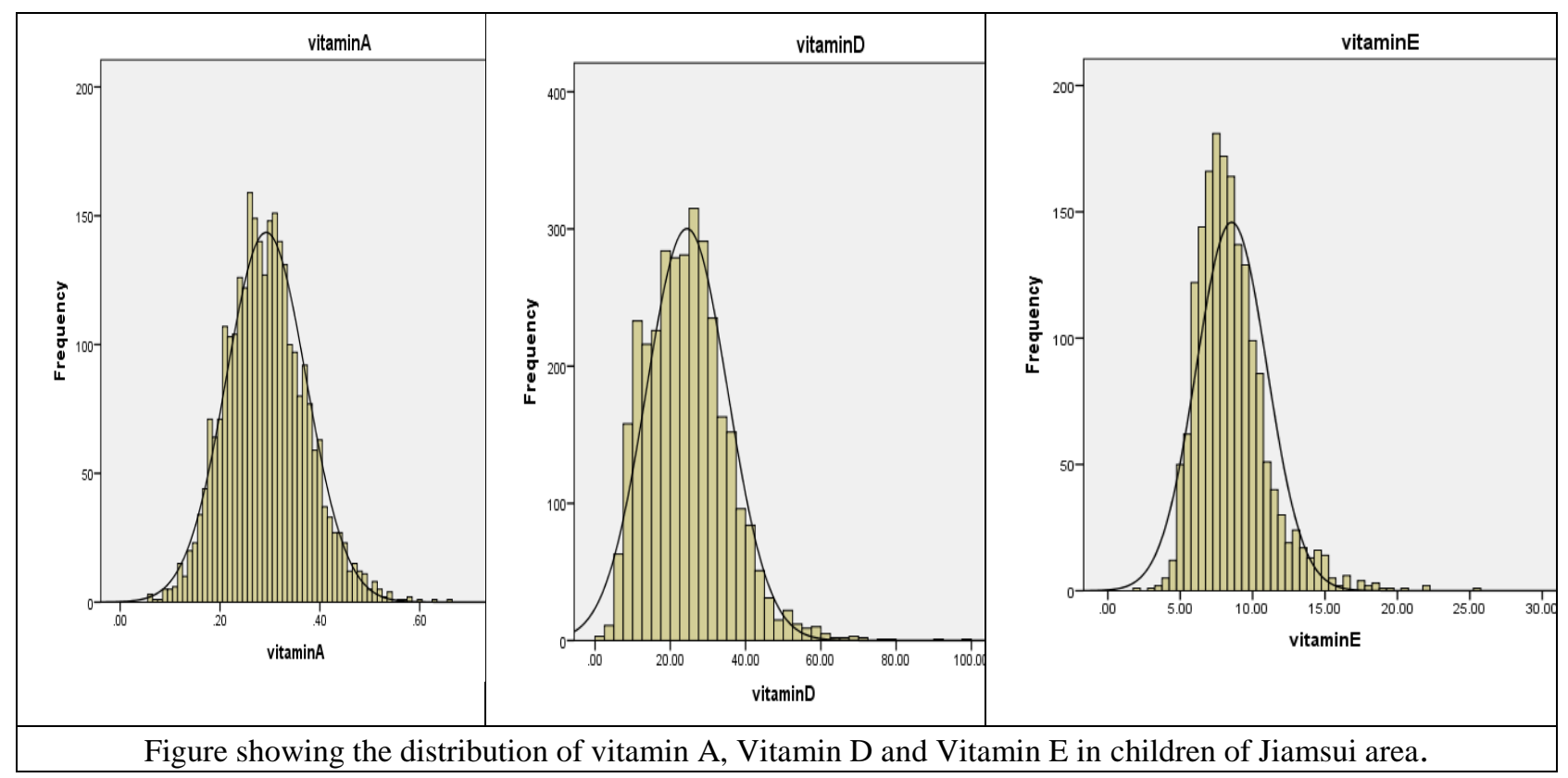

\section{Discussion:-}

Micronutrients plays crucial role in health and well being of any individual. These have even more special importance in children as they are growing and developing. The need for vitamin is different for different age group, different for different gender. Our study showedthe prevalence of vitamin A deficiency of 57.6\% showing more than half children deficit of vitamin A. This was coinciding with the study done by Chun yang et al [6] where it was found that most of part of china was having more prevalence of vitamin A deficiency. This could be due to the changing pattern of feeding habit. There is increasing trend of consumption of junk foods among children. There have been vast changes in the food and beverage. This diversity of food habit was also explained by the study done by wang $x$ et al [7] where he explained about the changing trend of feeding habit among Chinese children. This could explain the same result we had in our study. Western world children are also having similar changes in vitamin level which was explained in study done by mensrik et al [8] in children of UK, Poland and some western countries. They also have such change of feeding habit. Generally boys are more active in growing phase. They are more sports lovers and enjoy outdoor activities. This makes the boys needing more micronutrients. One of the study showed that the boys would need more vitamin A than girls as growth rates are higher before 10 years of age [9], which was coinciding with the result shown in male children of our study. Our study revealed that vitamin A deficiency is more common in younger children. The children from transition of breast feeding to other food had shown this pattern of vitamin A deficiency and the level is not fulfilled as children grow rapidly [10] which were coinciding with the Meta analysis done by Peige Song et al [11] where prevalence of VAD in younger children was seen. This could be due to the fatty food pattern and lowering activities among children in present days.

Vitamin D intake in American children was below 21\% in done by Mansbach et al [12], whereas the study done by Wang at el [13] in Wenzhou in china showed the prevalence of 38\%. The study said that there was supply of vitamin $\mathrm{D}$ due to sea fish which have good amount of vitamin D. Our study showed $36.9 \%$ of vitamin D deficiency. This may be due to lack of fresh food in northern parts and lack of sea food throughout the year. Jiamusi has less fresh food. Vegetables and poultry are imported from the south part. Wang LL study also showed the similar scenario of vitamin D deficiency. This study reflects prevalence of vitamin D all over china. We had significant difference between male and female children which coincides with the study done by Saintonge et al [14]. This could be due to less outdoor activities of female than boys. Chances of osteoporosis in females are more which was shown in one of the study done in Beijing coinciding higher prevalence of VDD in females [15]. Our study found the difference in season was significant with higher prevalence in winter and lesser prevalence of VDD in summer. Such pattern of variation was shown in the study done in Shanxi province by Strand MA et al [16]. Probably due to low sunlight, wearing of more clothes due to longer winter and less outdoor exposure could explain the low levels of vitamin $\mathrm{D}$ in 
northern part in winter season. More explanation matches with the result where vitamin D deficiency seen in summer is low and more vitamin D deficiency was prevalence in winter as extreme cold and longer snow covering remained for longer winter. Study done by Zhu et al [17] had shown that there was increasing vitamin D deficiency with increase of age. Study done by Schleicher et al [18] had shown that vitamin D was more common in 6-17 year children group than 1-11 years age group in US. Similarly study done by Sarafin k et al [19] in Canada had also shown more prevalence of vitamin D in 14-18 years of age group. Our study coincided with these two studies done out of China as we had similar older age group of children having more vitamin D deficiency. It may be due to more school work for children so that they won't get more time for physical activities. Older children generally take more junk foods which were relatively nutrients deficient. Infants were having high level of vitamin D. This may be due to supplementation of formula feed.

Vitamin $\mathrm{E}$ is an antioxidant which is very essential to human body. There was no clear cut trend of logics regarding the severity of vitamin E deficiency on basis of region, longitude, latitude and climate, prevalence was mostly affected by culture, life style of individual, nutritional pattern of children and presence of any infection in children during all time of sampling. When there was increased state of oxidative stress and lesser supply of antioxidants then patients showed bad prognosis [20, 21]. Our study did not show the significance differences with age group and gender. Study done by Khatib IM et al [22] showed the prevalence of $17.1 \%$ of VED when cut off was 5mg/L and $89.2 \%$ of VED when cut off was $7.5 \mathrm{mg} / \mathrm{L}$ in Jordan children. Farrell PM et al [23] showed Low vitamin E level in children ranging from 3-9 $\mathrm{mg} / \mathrm{L}$. Males supposed to have more vitamin E deficiency than females mostly due to PUFAs intake, alcoholic pattern and smoking pattern more in male. Females had higher level of tocopherol than males which was shown by the study done by Kang MJ et al [24]. The more the breast feeding, the lesser are the chances of having vitamin E deficiency. This was explained by study of Sinvichayakul et al [25] which showed that duration of breast feeding was having positive correlation with level of vitamin E. Study done by Winklhofer-Roob BM et al [26] showed that vitamin E had influence by age, sex and season of sampling. Season of sampling affected alpha tocopherol high in winter and gamma tocopherol higher in winter and spring than other season. Study done by Fares S et al [27] had shown that one fourth of children were having low vitamin E levels. Our study showed significance with season. It couldn't be explained why real significance exists in autumn season. Some researches done in animal has shown that there is decline of vitamin A and E in cow milk from autumn to winter [28]. One of the researches done in sheep has shown the prevalence of vitamin E was more in autumn due to deficiency of grass. These two can explain that the intake of this deficient food lead to vitamin E deficiency.

\section{Conclusions:-}

The prevalence of vitamin A deficiency and vitamin D deficiency is high in children of Jiamusi city area. The prevalence increases as child grow up. Vitamin D deficient more in winter whereas vitamin A deficient more in summer. Vitamin E was more deficient in autumn season. Supplement of vitamin A, D to elder children would reduce morbidity and mortality.

\section{Acknowledgement}

This work was supported by funding from the Youth Science Foundation Projects of Heilongjiang Province (No. QC2012C119), the Key Science and Technology Project of Jiamusi University (No.Sz2014-011), the National Cultivating Project of Jiamusi University (No. JMSUJCGP2016-005), the Youth academic backbone support project of Heilongjiang Province (No. 1253G057) and research projects Heilongjiang Provincial Health and Family Planning Commission (No. 2018-224).

\section{References:-}

1. Libo Tan, A.C.R., Vitamin A Deficiencies and Excess. Nelson Text Book of Pediatrics, Elseiver, First South Asian Edition, 2016. 1(Chapter 48): p. 317-321.

2. Holick, M.F. and T.C. Chen, Vitamin D deficiency: a worldwide problem with health consequences. Am J Clin Nutr, 2008. 87(4): p. 1080s-6s.

3. Palermo, N.E. and M.F. Holick, Vitamin D, bone health, and other health benefits in pediatric patients. J Pediatr Rehabil Med, 2014. 7(2): p. 179-92.

4. Dror, D.K. and L.H. Allen, Vitamin E deficiency in developing countries. Food Nutr Bull, 2011. 32(2): p. 124-43. 
5. Burris CA, A.E., Burns DE, Tietz textbook of Clinical Chemistry and Molecular Diagnosis. Louis; Elseiver Saunders, 2012.

6. Yang, C., et al., Comparison on the status of vitamin A in 6- to 13-year-old children between 2002 and 2012 in China. Nutr J, 2016. 15(1): p. 50.

7. H., W.X.S.C.O.Y.L.W.Z.B.W., Trends of Chinese in dietary pattern of children and adolescents in communities at different urbanization levels. . Acta Nutr. Sin., 2016. 38: p. 119-123.

8. Mensink, G.B.M., et al., Mapping low intake of micronutrients across Europe. British Journal of Nutrition, 2013. 110(4): p. 755-773.

9. Nations, W.H.O.a.F.a.A.O.o.t.U., Vitamin and mineral requirement in human nutrition. WHO Library Cataloguing-in-Publication Data, WHO statistics, 20052005.

10. China, D.o.P.a.E.S.o.t.N.B.o.S.o., China Population and Employment Statistics Yearbook 2016. China Statsitics Press: Beijing, China, 2016.

11. Song, P., et al., The Prevalence of Vitamin A Deficiency in Chinese Children: A Systematic Review and Bayesian Meta-Analysis. Nutrients, 2017. 9(12).

12. Mansbach, J.M., A.A. Ginde, and C.A. Camargo, Jr., Serum 25-hydroxyvitamin D levels among US children aged 1 to 11 years: do children need more vitamin D? Pediatrics, 2009. 124(5): p. 1404-10.

13. Wang, L.L., et al., Vitamin D status among infants, children, and adolescents in southeastern China. J Zhejiang Univ Sci B, 2016. 17(7): p. 545-52.

14. Saintonge, S., H. Bang, and L.M. Gerber, Implications of a new definition of vitamin $D$ deficiency in a multiracial us adolescent population: the National Health and Nutrition Examination Survey III. Pediatrics, 2009. 123(3): p. 797-803.

15. Foo, L.H., et al., Relationship between vitamin $D$ status, body composition and physical exercise of adolescent girls in Beijing. Osteoporos Int, 2009. 20(3): p. 417-25.

16. Strand, M.A., et al., Severe vitamin D-deficiency and the health of North China children. Matern Child Health J, 2009. 13(1): p. 144-50.

17. Zhu, Z., et al., High prevalence of vitamin $D$ deficiency among children aged 1 month to 16 years in Hangzhou, China. BMC Public Health, 2012. 12: p. 126.

18. Schleicher, R.L., et al., National Estimates of Serum Total 25-Hydroxyvitamin $D$ and Metabolite Concentrations Measured by Liquid Chromatography-Tandem Mass Spectrometry in the US Population during 2007-2010. J Nutr, 2016. 146(5): p. 1051-61.

19. Sarafin, K., et al., Standardizing 25-hydroxyvitamin $D$ values from the Canadian Health Measures Survey. Am J Clin Nutr, 2015. 102(5): p. 1044-50.

20. Allard, J.P., et al., Effects of vitamin $E$ and $C$ supplementation on oxidative stress and viral load in HIV-infected subjects. Aids, 1998. 12(13): p. 1653-9.

21. Allard, J.P., et al., Oxidative stress and plasma antioxidant micronutrients in humans with HIV infection. Am J Clin Nutr, 1998. 67(1): p. 143-7.

22. Khatib, I.M. and I. Elmadfa, Poor nutritional health of Bedouin preschool children in Jordan: the irony of urbanization. Ann Nutr Metab, 2009. 54(4): p. 301-9.

23. Farrell, P.M., et al., Plasma tocopherol levels and tocopherol-lipid relationships in a normal population of children as compared to healthy adults. Am J Clin Nutr, 1978. 31(10): p. 1720-6.

24. Kang, M.J., et al., Vitamin E status and its dietary determinants in Taiwanese--results of the Nutrition and Health Survey in Taiwan 1993-1996. Eur J Nutr, 2004. 43(2): p. 86-92.

25. Sirivichayakul, C., et al., Plasma retinol and alpha-tocopherol level and growth indices of 7 months old healthy Thai infants in Bangkok. Southeast Asian J Trop Med Public Health, 2001. 32(2): p. 40812.

26. Winklhofer-Roob, B.M., M.A. van't Hof, and D.H. Shmerling, Reference values for plasma concentrations of vitamin $E$ and $A$ and carotenoids in a Swiss population from infancy to adulthood, adjusted for seasonal influences. Clin Chem, 1997. 43(1): p. 146-53.

27. Fares, S., et al., Status of vitamins $A$ and $E$ in schoolchildren in the centre west of Tunisia: $a$ population-based study. Public Health Nutr, 2011. 14(2): p. 255-60.

28. Adeela Yasmin, N.H., Masood Sadiq Butt, Tahir Zahoor, Muhammad Yasin *, Seasonal variation in milk vitamin contents available for processing in Punjab, Pakistan. Journal of the Saudi Society of Agricultural Sciences, 2012. 11: p. 99-105. 